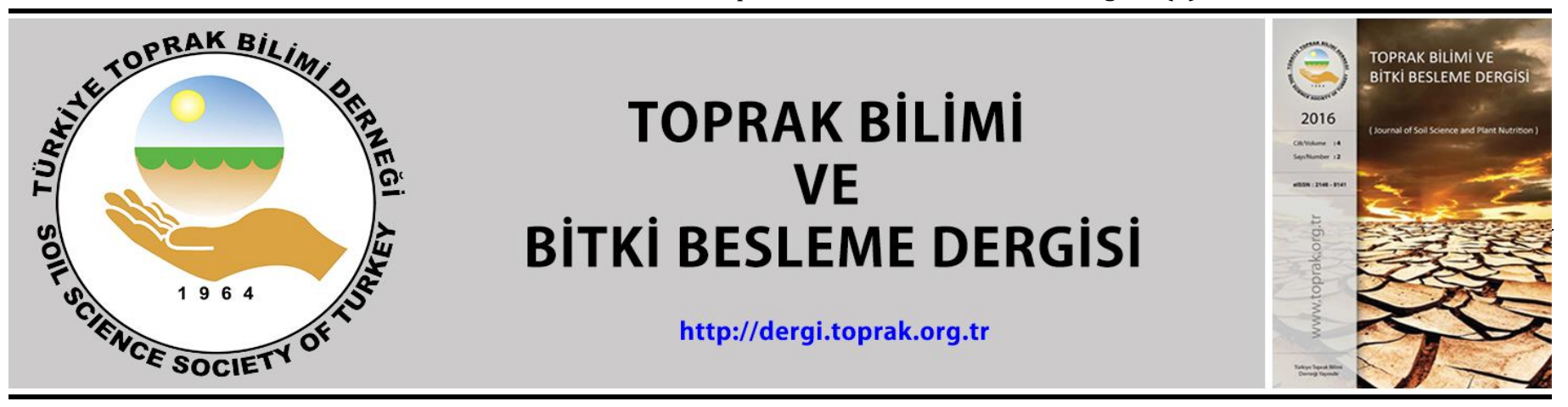

\title{
Domates bitkisinin tuz stresine karşı tepkisinde Nano Zn-Biyo gübre formülasyonlarının etkisi
}

\author{
Kağan Tolga Cinisli, Nesrin Yıldız *
}

Atatürk Üniversitesi, Ziraat Fakültesi, Toprak Bilimi ve Bitki Besleme Bölümü, Erzurum

\section{Özet}

Çalışmanın amacı, çinkooksit nanopartikülleri (ZnO-Nps) ile Bacillus grubu (Bacillus subtilis (N28), Bacillus pumilis (N1) ve peynir kökenli Lactobacillus casei (Nm24) bakteri formülasyonun tuz stresi koşullarında domates bitkisinin gelişimi ve mineral içeriği üzerine etkilerinin araștırılmasıdır. Domates bitkisine tuz stresi oluşturmak amacıyla, $100 \mathrm{mg} \mathrm{L}^{-1}$ çinkooksit nanopartikülleri ile birlikte 50 mMolar $\mathrm{NaCl}$ tampon karışımı hazırlanmıştır. Bu tampon mikroorganizmalar üzerinde standart disk difüzyon yöntemi kullanılarak petrilere yerleştirilip disklere $(30 \mu \mathrm{g})$ emdirilerek bakterilere uygulanmıștır. Bu koşullarda, canlılıklarını devam ettiren üç mikroorganizma (Bacillus subtilis (N28), Bacillus pumilis (N1) Lactobacillus casei (Nm24) seçilerek taramalı elektron mikroskobu (SEM) ve RAMAN spektroskopisi ile gözlemlenmiştir. Tuzluluk koşullarında denek bitki olarak Linda (Lycopersicon esculentum) seçilmiş ve sera koşullarında yetiştirme ortamı olarak her saksıya $1 \mathrm{~kg}$ kum ve $0,3 \mathrm{~kg}$ turba yosunu; üç doz çinko nanopartikül $(0$, 20, $40 \mathrm{mg} \mathrm{L}^{-1}$ Zno-Nps), 3 bakteri [Bacillus pumilis (N1), Bacillus subtilis (N28), Lactobacillus casei (Nm24)], karışım formülasyonları hazırlanarak dört tekrarlı olacak șekilde deneme kurulmuștur. Olușturulan formülasyon bir dekarlık alan için 100 litre hesabı temeline dayalı olarak suya karıştırılıp uygulanmıștır. Uygulamaların kuru madde miktarı, bitkinin besin element içeriği üzerine etkisi (azot $(\mathrm{N})$ potasyum (K), kalsiyum (Ca), magnezyum (Mg), fosfor (P), demir (Fe), bakır (Cu), çinko (Zn), mangan(Mn), bor (B)) içeriği üzerine etkileri değerlendirilmiştir. Uygulamalar sonucunda kuru madde içeriğinin $(\% 31,2)$, fosfor içeriği \%15,64, potasyum içeriği \% 2,75, kalsiyum içeriğini \% 8,2, magnezyum içeriği \% 17,19, B. subtilis (N28)+40 ZnNanops uygulama grubu çinko içeriği \%19,01, demir içeriği \% 7,75, mangan içeriği \% 14,6, B bakır içeriğini \% 12,71, B. pumilis bor içeriğini \% 23,8, toplam azot içeriğinin ise yaklaşık 3 kat arttırdığı gözlemlenmiştir. Araştırma sonucuna göre tuz stresi altında bitkilerin fotosentetik tepki olarak tuz stresinden kurtulma adına karbonhidrat metabolizmasını köke yönledirmesine neden olmuştur. Ürün verim ve verim unsurlarında meydana gelen kaybın azaltılması yönünde nanoboyutta çinko partikülleri ile Bacillus pumilis (N1), Bacillus subtilis (N28), Lactobacillus casei (Nm24) kombinasyonu bu tepkinin yönetilmesinde istatsitiksel anlamda önemli katkılar sağlamıştır. Bitki besin ve iyon dengesinin sağlanmasına katkıları yanında enzimsel etki mekanizması yaratarak bitkinin bu stresini azaltma yönünde önemli etkileri olmuştur. Özellikle önümüzdeki 20-30 yıllık süreç içerisinde iklim bilimcilerinin ortaya koyduğu seneryolara göre bitkisel üretimde bu tür sorunların giderek artacağı yönündeki gelişmelere karşı bu yöndeki sorunlara çözüm olabilme yönüyle oldukça anlamlı bir çalışmadır. Bu çalışmanın tarla koşullarında yapılacak çalışmalar ile kalibre edilmesi durumunda farklı tuz stresi koşullarına göre mevcut formülasyonların yada ilave gerekli nanobesinlerin verilmesi gerekli olabilmektedir.

Anahtar Kelimeler: Nanopartikül, çinko, bacillus, tuz, stres, domates.

\section{Effect of Nano $\mathrm{Zn}$-Bio fertilizer formulation on the response of tomato plant against salt stress}

\section{Abstract}

The objective of this study was to determine the effects of zinc nanoparticles (ZnO-Nps) and Bacillus group bacteria on plant growth (dry matter production) and mineral content of tomato under salt stress conditions. For creating salt stress for tomato, $100 \mathrm{mg} / \mathrm{L}-1$ zinc oxide nanoparticles were mixed with 50 Mmolar $\mathrm{NaCl}$ buffer. This buffer mixture was applied to bacteria using the standard disk diffusion method, $30 \mu \mathrm{g}$ mixing buffer was applied to the disks. Three microorganisms (Bacillus subtilis (N28), Bacillus pumilis (N1) Lactobacillus casei (Nm24) were selected and observed by scanning electron microscopy (SEM) and Raman spectroscopy. Linda (Lycopersicon esculentum) was selected as the experimental plant in greenhouse conditions, $1 \mathrm{~kg}$ sand and 0,3 kg peat moss per pot were prepared and three doses of zinc nanoparticles (0, 20, $40 \mathrm{mg} \mathrm{L}-1 \mathrm{ZnO}-\mathrm{NPS}$ ), 3 bacteria [Bacillus pumilis (N1), Bacillus subtilis (N28), Lactobacillus casei $(\mathrm{Nm} 24)$ were tested with four replications. The prepared formulation was mixed with water and applied with a rate of 100 liter per decare. The effects of treatments on dry matter content, plant on nutrient content (nitrogen (N) potassium $(\mathrm{K})$, calcium $(\mathrm{Ca})$, magnesium $(\mathrm{Mg})$, phosphorus $(\mathrm{P})$, iron $(\mathrm{Fe})$, copper $(\mathrm{Cu})$, zinc $(\mathrm{Zn})$, manganese $(\mathrm{Mn})$ and boron $(\mathrm{B})$ contents were evaluated. The results indicated that the increasing rates in dry matter content, phosphorus, potassium, calcium, magnesium, zinc, iron, manganese, cupper, boron and total nitrogen contents of leaf were 31.3\% 15,64 \%, 2,75\%, 8.2 \%, 17,19\%, $19,01 \%, 7,75 \%, 14,6 \%, 12,7123.8 \%$ respectively, with B. subtilis (N28)+40 Znanops application. It was clearly shown that the

\footnotetext{
* Sorumlu yazar:

Tel. : $\quad$ : 04422312464

E-posta : nyildiz@atauni.edu.tr
}

Geliş Tarihi Kabul Tarihi
6 Ağustos 2019

23 Kasım 2019
e-ISSN

DOI : $10.33409 /$ tbbbd.668898 


\begin{abstract}
combination of zinc particles and Bacillus pumilis (N1), Bacillus subtilis (N28), Lactobacillus casei (Nm24) in nanoparticles had statistically significant effect on reducing crop yield loss and yield properties under salt stress conditions. Plant nutrients and ion balance in addition to their contribution to the enzymatic effect mechanism creating the plant has important effects in reducing stress. Especially in the next 20-30 years, according to scenario put forward by climatic scientists, this kind of problems in plant production will increase gradually against developments in this direction is a very valuable work in terms of solution to problems. If this study is calibrated with the studies to be done in field conditions, it may be necessary to give the existing formulations or additional needed Nano particular nutrient in the different salt stress conditions.
\end{abstract}

Keywords: Nanoparticle, zinc, bacillus, salt, stress, to mato

(C) 2019 Türkiye Toprak Bilimi Derneği. Her Hakkı Saklıdır

\title{
Giriş
}

Tuz stresi altındaki pekçok bitki, beslenme dengesizliklerinin bir sonucu olarak, oksidatif ve mekanik veya sekonder streslerden de etkilenir. ZnO-NP'ler, bitkilerde abiotik strese karşı tanınma ve yanıtta yer alan çeşitli mekanizmaların düzenlenmesinde güçlü bir rol oynamaktadır (Prasad ve ark., 2012). Yüksek bitkilerdeki tuzluluk ile $\mathrm{ZnO}$ arasındaki etkileşime ilişkin raporlar giderek artmaktadır, ancak halihazırda tuz stresinden kaynaklanan zararları azaltmak için ZnO-NP uygulamalarının olası yararlı etkileri hakkında çok az sayıda bilgi mevcuttur. Tuz stresi altında, Reaktif Oksijen Türlerinin (ROS) hücre içi düzeylerindeki artışların, hücre yapılarında ciddi hasarlara neden olduğu ve SOD ve GPX gibi bir dizi genin ekspresyonunu etkilediği görülmüştür (Gill ve Tuteja, 2010). Reaktif oksijen türleri (ROS), bir dizi genin ekspresyonunu etkilediği bilinmekte ve tuzluluk tarafından indüklenen abiyotik stres tepkilerinde birçok işleme katkıda bulunmaktadır.

Zhao ve ark. (2014) tarafından yapılan bir sera çalışmasında bir toprak karışımına 400 ve $800 \mathrm{mg} \mathrm{kg}^{-1} \mathrm{ZnO-}$ NP uygulanmasının ardından salatalık biyokütlesini arttırdığını bildirmişlerdir. Sonuçlar, meyvelerin kuru ağırlığının, kontrol grubuna kıyasla sadece \% 6 ve \% 8 oranında artmasına rağmen, bitki kökü kuru kütlesinin kontrol grubuna göre 1,1 ve 1,5 kat daha yüksek olduğunu ortaya koymuştur. Hasat edilmiş salatalık meyvelerinde, ZnO-NP'lerin uygulanması da, nişasta içeriğini (1.1-1.6 kat), glutelin (0.9-2 kat) ve Zn'yi (1.7-2.5 kat) arttığını bildirmiştir (Zhao ve ark., 2014). Lin ve Xing (2007), 2 mg L-1 ZnO-NP uygulanmasının çimlendirilmiş turp tohumlarının kök uzamasını kontrole göre arttırdığını bildirilmişlerdir. Optimum konsantrasyonlarda Zn-NP'lerin kullanılması bu fideler üzerinde önleyici veya toksik etkilere sahiptir. Bununla birlikte, bu raporların hepsinde ZnO-NP'lerin ciddi fitotoksisitesi, 400 ila $2000 \mathrm{mg} \mathrm{L}^{-1}$ arasındaki yüksek NP-Zn konsantrasyonlarında olduğu anlaşılmıştır (Lopez ve Satti, 1996; Lin ve Xing, 2007; Lee ve ark., 2010; Zhao ve ark., 2014). Zn nanomateryallerin çözünürlügü, boyut, spesifik yüzey alanı, tepkimelerden etkilenmeyecek oluşu gübre olarak kullanılabileceğinin göstergesi olmuştur (Subramanian ve Sharmila, 2012; Mosanna ve Khalilvand, 2015). Örneğin sebzelerin tohumdan çimlenmesine çinko'nun olumsuz etkisi görülürken nano boyuttaki çinkooksit (ZnO) nanopartiküllerinin olumlu etkileri görülmüștür (Prasad ve ark., 2012). Fistık tohum çimlenmesi, yaprak klorofil içeriği, kök ve gövde büyümesi, üzerine olumlu etkilerinin olduğu ortaya çıkmıștır (Singh ve ark., 2013). Tuza dayanıklılık yönünden değișik bitkiler arasında önemli farklılıklar görülebilir. Bitki dokularında K iyonu ile bitki polimerleri (Pas) arasında ilişki olduğu saptanmıștır (Smith 1985; Flores ve Galston 1982; Iqbal ve Ashraf, 2006). Ayrıca tuz stresi kosullarında bitki bünyesinde poliaminlerin birikimi görülmektedir. Tuz stesi koşullarında bitki dokularında iyon birikimi olduğu gibi poliaminlerin de biriktiği görülmüștür. Domates bitkisinin tuz stresi koşulları altında SOD ve GPX gen ekspresyonlarının değiștiği ortaya çıkmıştır (Gill ve Tuteja, 2010). Bitkiler tuz stresine karşı kendi metabolizmasını ayarlayarak bir savunma mekanizması oluşturmak için bünyelerinde bazı sinyal yollarını aktive ederek tuz stresine cevap verirler (Khan ve ark., 2016). Bu stratejiler stomaların kapanması ozmotik iyon taşıyıcılar, sekonder metabolitlerin taşınmasını içerir. Fitohormonlar yani salisilik asit (SA), jasmonik asit (JA), ve absisik asit (ABA) tuz stresine yanıt olarak hayati bir önem taşımaktadırlar (Kazan, 2015). Alharby ve ark. (2016) yapmış oldukları çalışmada NaCl stres altındaki her iki düzeyde (15 ve $30 \mathrm{mg} \mathrm{L}^{-1}$ ) ZnO-NPs ile işlenmiş domates bitkilerinin, SOD ve GPX genleri mRNA ekspresyon seviyesinde arttığı gözlemlenmiştir. Görünüşe göre, ZnO-NP'lerin varlığı domates bitkilerinde mRNA'nın aktivitesini değiștirebilir ve bu tuzluluk stresi karşısında iyileştirici etki gösterebilir. Bunun için muhtemel bir açılama, ZnO-NP'lerin düşük ve/veya uygun dozunun, bitki metabolizması üzerinde pozitif bir tepkiye sahip olduğunu belirten, daha sonra etkilenen azot gibi temel besin maddelerinin emilimi, iyon homeostazı, osmolitik biyosentez, protein içeriği ve toksik radikal türetmenin arttırıldığı ortaya çıkmıştır (Laware ve Raskar, 2014). Bununla birlikte, SOD ve GPX genlerinin mRNA düzeylerindeki artışları, transkripsiyonlu mRNA'ların artmış kararlılığının bir sonucu olabilir (Soydam ve ark., 2013). 
Bu çalışmanın amacı; nanomateryaller ve bitkiler açısından faydalı mikroorganizmaları içeren yeni bir formülasyonun oluşturulup, bitki gelişimini stres koşullarında teşvik etme potansiyeline sahip yeni bir ürünün oluşturulma basamaklarından bir kısmını esas almaktadır.

\section{Materyal ve Yöntem}

Araştırmada mineral gübre kaynağı olarak çinkooksit nanopartikülleri (cas number 1314-13-2, <100 nm particle size (TEM), $\leq 40 \mathrm{~nm}$ avg. part. size (APS), 20 wt. \%in $\mathrm{H}_{2} \mathrm{O}$ ) sigmadan hazır olarak satın alınmıș, kullanılan mikroorganizmalar Atatürk Üniversitesi Ziraat Fakültesi Tarımsal Biyoteknoloji Bölümünden temin edilmiş, denek bitki olarak domates bitkisinin Linda çeşidi (Lycopersicon esculentum) fide olarak temin edilmiş olup sera denemesinde tuzluluk stresine indikatör bitki olarak kullanılmıştır. Bitkinin yetiştirilme ortamı olarak kum ve turba yosun karışımı (w/w, 3/1) oranında kullanılmıştır. Biyo canlılığın sürdürülebilirliğini sağlamak için ortam olarak şilempe kullanılmıştır.

\section{Saf bakteri kültürlerinin besiyeri ortamında geliştirilmesi ve sterilizasyonu}

Nutrient agar ve M17 besiyerleri hazırlanarak $121^{\circ} \mathrm{C}$ de $15 \mathrm{dk}$ steril edildikten sonra $45^{\circ} \mathrm{C}$ ye kadar soğutularak steril petrilere dökülerek katılașmaya bırakılmıştır.

\section{Disk difüzyon yöntemi ile nanopartiküllerle birlikte tuzlu koşullarda gelişimini sürdüren bakterilerin seçimi}

50 mMolar $\mathrm{NaCl}$ ve $100 \mathrm{mg}$ L-1 çinkooksit nanopartikülleri birlikte tampon karışımı hazırlanmıştır. Yirmi mikroorganizma üzerinde MuellerHintonagar besiyeri standart disk difüzyon yöntemi kullanılarak petrilere yerleştirilen disklere $30 \mu \mathrm{l}$ karışım tampon emdirilmiştir. 3 gün sure ile 37 de etüvde bekletildikten sonra üç mikroorganizmanın (Bacillus subtilis (N28), Bacillus pumilis (N1) ve peynir kökenli Lactobacillus casei (Nm24) petrilerinde disk çevresinde üremenin görüldügü tespit edilmiştir (Şekil 1-4).

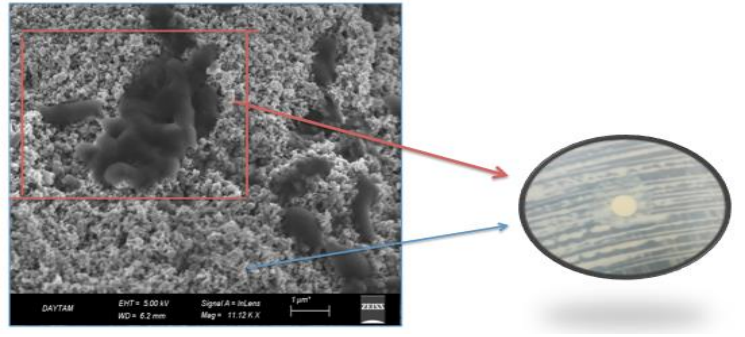

Şekil 1. Taramalı elektron mikroskobu (SEM) ile Lactobacillus casei (Nm24) için disk difüzyon yöntemi kullanılarak nanopartiküllerle olan sinerjik etkisi

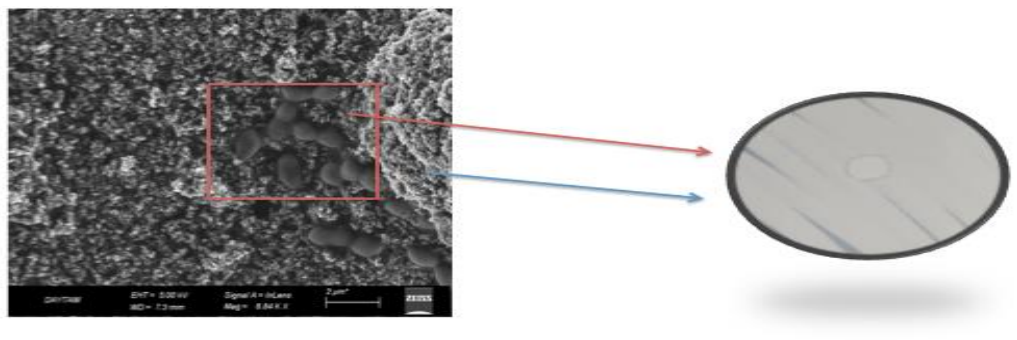

Şekil 2. Taramalı elektron mikroskobu (SEM) ile Bacillus pumilis (N1) için disk difüzyon yöntemi kullanılarak nanopartiküllerle olan sinerjik etkisi

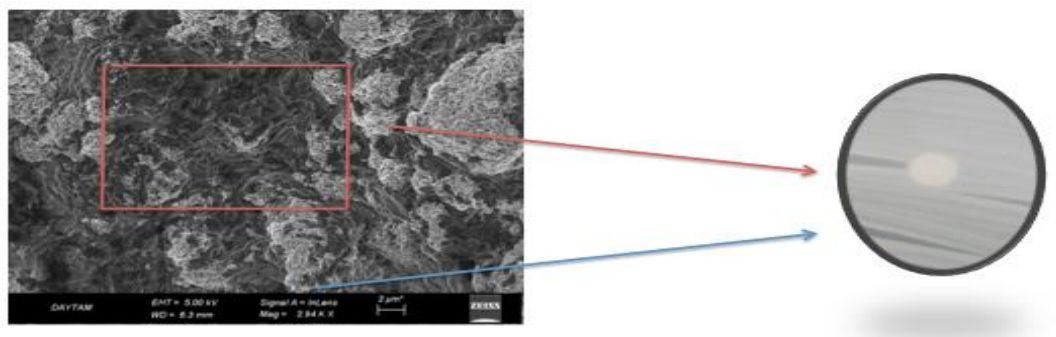

Şekil 3. Dayanıklı mikroorganizmaların seçimi için karışım tamponunun disklere emdirilerek petrilere yerleştirilmesi

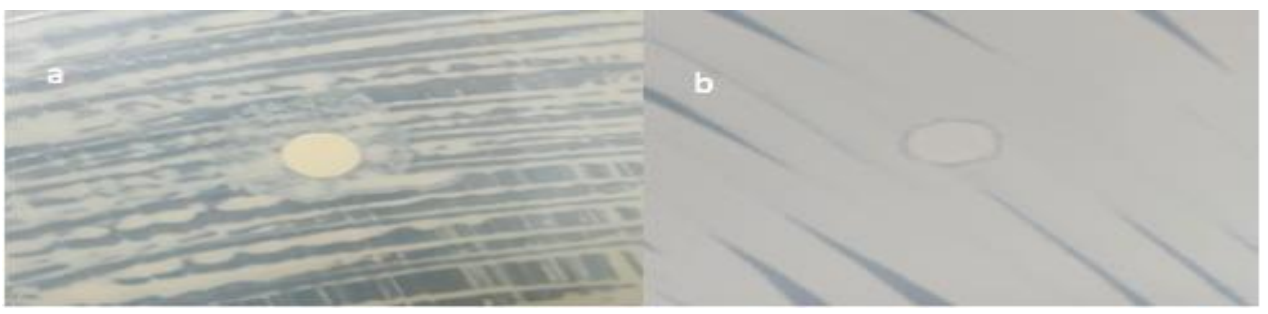

Şekil 4. Disklere emdirilen karışım tamponunun 20 mikroorganizma da denenmesi a) Mikroorganizmaların seçiminde nanopartikül ve tuz karışımına karşı canlılıklarını devam ettirebildiği b) Mikroorganizmaların nanopartikül ve tuz karışımına karşı canlılıklarını devam ettiremediğinin göstergesidir. 


\begin{abstract}
Nano-biyo gübrenin taramalı elektron mikroskobu (SEM) görüntüleri
Nanopartikülün hazırlanan formülasyon içerisindeki morfolojik analizleri için Taramalı Elektron Mikroskobu (SEM) kullanılmıştır. SEM analizinde iletkenliğini sağlamak için örnekler altınla kaplanmıștır. Bu kaplamadaki amaç altının yüksek iletkenlik ve oksitlenmeme özelliğinin olmasıdır. $20.000 \mathrm{x}, 30.000 \mathrm{x}$ ve 50.000 x olarak üç farklı büyütme oranlarıyla nanopartiküllerin SEM görüntüleri alınmıştır.
\end{abstract}

\title{
Nano-biyo gübrenin RAMAN spektroskopisi ile görüntüleri
}

Oluşturduğumuz formülasyonun nanopartikül içeriğinin iyice doğrulanması adına kullanılan nanopartiküllerin molekülleri içerisindeki bağlar ve bu bağların üzerine düşürülen ışı̆̆ı esnek olmayan şekilde saçması yöntemine göre çalışan RAMAN spektroskopisi ile doğrulamak amacıyla $785 \mathrm{~nm}$ lik lazer kaynağı ile çinkooksit nanopartikülleri analiz edilmiştir (Şekil 5). Genel olarak oluşturulan formülasyonda 10 mikrometrelik mikroorganizmalar üzerindeki $\mathrm{ZnO}$ nanopartiküllerin genel olarak yüzde 22 si nanopartikül geri kalan kısmı ise mikroorganizmalardan oluşmaktadır.

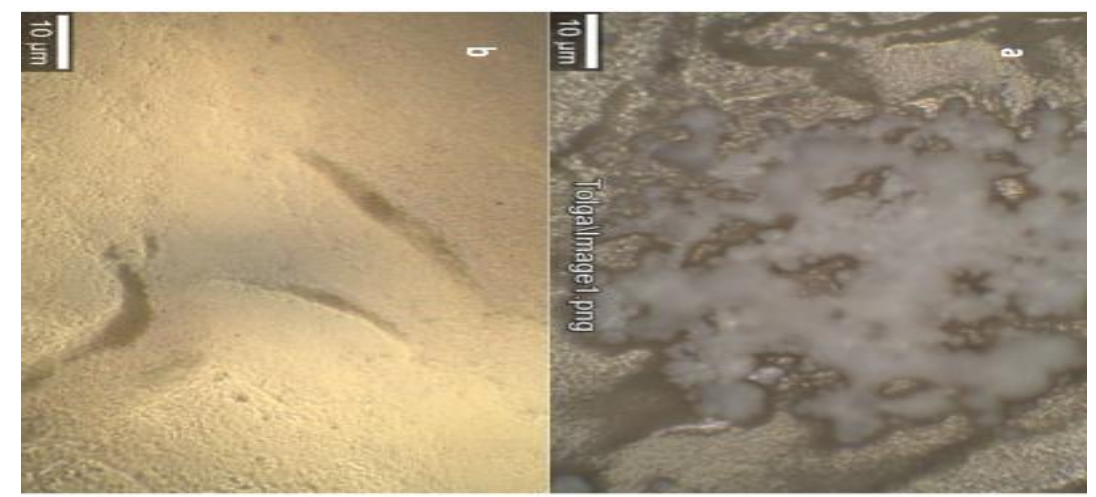

Şekil 5. Raman cihazıyla nano-biyo gübrenin a) ZnO nanopartikülü görüntülenmesi b) Bakteri yüzey görüntülenmesi

Dökme plaka yöntemi ile bakterilerin (Bacillus Subtilis (N28), Bacillus Pumilis (N1) Lactobacillus Casei (Nm24) sayımlarının yapılması

Bakteri stok suşlarından 100 mikrolitre alınarak son hacim $1 \mathrm{ml}$ olacak şekilde fizyolojik tuzlu su içerisinde çözündürülerek $10^{-1}$ lik ilk dilüsyon hazırlanmıștır. Her bir dilüsyondan iki steril petri kutusuna birer $\mathrm{ml}$ aktarılmış ve üzerine $45^{\circ} \mathrm{C}$ 'ye soğutulmuştur. $37{ }^{\circ} \mathrm{C}$ 'de 48 saat inkübasyona bırakılmıştır (48 saatte üreme olmazsa petriler 24 saat daha inkübasyona tabi tutulur). Oluşan koloniler sayllarak (kob/ml olarak) hesaplama yapılmıştır. Hesaplama yapılırken, ard arda iki seyreltmeden yapılan ekim sonuçlarının aritmetik ortalaması alınmış numune içindeki mikroorganizma sayısı hesaplanmıştır. Hesaplamada kullanılan formül; $\mathrm{N}=\mathrm{C} /[\mathrm{V} \times(\mathrm{n} 1+0,1 \times \mathrm{n} 2) \times \mathrm{d}]$ şeklindedir. 12 Burada; $\mathrm{N}=$ örneğin Bir gram veya 1 ml'sinde mikroorganizma sayısı $C=$ Sayımı yapılan tüm petri kutularında bulunan koloni sayısı toplamı $V=$ Sayımı yapılmış petri kutularına aktarılan hacim miktarı $(\mathrm{ml}) \mathrm{n} 1=$ ilk seyreltmeden yapılan sayımlarda sayım yapılan petri kutusu adedi $\mathrm{n} 2=$ ikinci seyreltmeden yapılan sayımlarda sayım yapılan petri kutusu adedi $d=$ Sayımın yapıldığı ardışık iki seyrelti

\section{Bakterilerin canlılık testi ve sıvı taşıyıcı ortamın seçilmesi}

Bakterilerin formülasyonlarımız içerisinde yaşamlarını devam ettirebilmeleri için taşıyıcı ortam olarak şeker şurubu şilempe kullanılmıştır. Şilempe saf su ile (w/w, 1/10, 1/20,1/50,1/100) oranında seyreltilerek üç farklı bakteri türüne uygulanmıştır. Uygulamada $1 / 100$ seyreltmede bakterilerin ürediği görülmüş elde edilecek ürünün maliyetinin daha düşürmek adına bu seyreltik oran formülasyonlar için kullanılmıştır.

\section{Deneme deseni ve deneme konuları}

Ülkemizde yaygın olarak kullanılan Linda domates (lycopersicon esculentum mill) çeşidi tuz stresine maruz bırakılmıştır. Tam şansa bağlı deneme modeline $(3 \times 3 \times 4)$ göre çalışma üç doz $\left(0,20,40 \mathrm{mg} \mathrm{L}^{-1}\right.$ Zno-Nps (sigma cas number 1314-13-2, <100 nm particle size (TEM), $\leq 40 \mathrm{~nm}$ avg. part. size (APS), 20 wt. \% in H20) $\times$ 3 bakteri [Bacillus pumilis $\left(5,7 \times 10^{7} \mathrm{cfu} / \mathrm{ml}\right) \mathrm{N} 1$, Bacillus subtilis $\left(1 \times 10^{8} \mathrm{cfu} / \mathrm{ml}\right) \mathrm{N} 28$, Lactobacillus casei $\left.\left(2,9 \times 10^{8} \mathrm{cfu} / \mathrm{ml}\right) \mathrm{Nm} 24\right] \times 4$ (tekerrür) olacak şekilde deneme kurulmuştur. Oluşturulan bir litrelik formülasyon 1 dekarlık alana 100 litre saf suya karıştırılıp uygulanacak şekilde ayarlanmıştır. Bitki fideleri $10 \mathrm{~cm}$ lik derinlikte saksılara yerleştirilecek yetişme ortamı olarak kuartz kum ve turba yosunu (1:3) oranında karıștırılarak 1,1 litrelik $(30 \mathrm{~cm})$ saksılara uygulanmıştır. Oluşturulan formülasyonda bakteriler için sıvı taşıyı ortam olarak şilempe kullanıldığı için v/v 1/100 olarak şekilde uygulanmıştır. Bitkinin besin ihtiyacını karşılamak Arnon (1938) besin çözeltisi uygulamaları haftada bir kez yapılmıştır. Bitkilere yapay 
tuz stresi yaratmak için sodyum klorür ile (Kotuby ve ark., 1997; Bayrakll, 1998; Kanber ve ark., 1992) muameleler, 3-4 yapraklı fideler saksılara aktarıldıktan hemen sonra uygulanmaya başlanmıștır. $\mathrm{NaCl} 50$ mM saksılara haftada üç kez uygulanmıştır. Uygulama Atatürk Üniversitesi Ziraat Fakültesi seralarında sürdürülmüştür.

\section{Fide Temini Bakım, Hasat İşlemleri ve Örnekleme İşlemlerinin Yapılışı}

Linda çeşidi domates fideleri Akdeniz bölgesi Antalya ilinden temin edilmiştir. Denemeler Atatürk Üniversitesi Ziraat Fakültesi Toprak Bilimi ve Bitki Besleme Bölümü seralarında saksılarda kurulmuş ve doğal ışık altında yürütülmüştür. Biyolojik gübre ile nanopartikül karışım süspansiyonları tuz stresi altında yetiştirilen bitkilerin kök bölgesine enjekte edilmiştir. Deneme periyodu boyunca bitkilere kimyasal ilaç uygulanması yapılmamış, yabancı ot elle kontrol edilmiştir. Tuz stresi koşullarına bağlı olarak iki ay çalışma sürdürülmüş, kontrol grubunun durumu ve çiçeklenme dönemi dikkate alınarak hasat işlemi gerçekleştirilmiştir. Saksı içeriğinin tamamı örneklenmiştir. Örnekler ylkanmış, $65^{\circ} \mathrm{C}^{\prime}$ ye ayarlı kurutma dolabında son tartım sabit kalıncaya kadar kurutulmuş ve bitki ögütme değirmeninde ögütülerek analize hazır hale getirilmiştir (Kacar ve İnal, 2008).

\section{Elementel analiz (Sodyum, Potasyum, Kalsiyum, Demir, Bakır, Çinko, Mangan, Fosfor, Magnezyum, Bor)}

Domates örneklerinin $\mathrm{P}, \mathrm{K}, \mathrm{Mg}$, $\mathrm{Ca}, \mathrm{Fe}, \mathrm{Na}, \mathrm{Mn}, \mathrm{Zn}, \mathrm{Cu}$, ve B içerikleri nitrik asit-hidrojen peroksit (2:3) asit ile üç aşama (1. aşama; $145^{\circ} \mathrm{C}$ de $\% 75$ mikrodalga gücün de 5 dakika, 2 . așama; $180^{\circ} \mathrm{C}^{\prime}$ de $\% 90$ mikrodalga gücün de 10 dakika ve 3 . aşama $100^{\circ} \mathrm{C}^{\prime}$ de $\% 40$ mikrodalga gücün de 10 dakika) 40 bar basınca dayanıklı olan mikrowave yaş yakma ünitesinde (speedwave MWS-2 Berghof productts + Instruments Harresstr.1. 72800 Enien Gernmany) yakılmış (Mertens, 2005a) sonra ICP-OES spektofotometresinde okunmak suretiyle belirlenmiştir (Mertens, 2005b).

\section{Toplam Azot Tayini}

Bitki örneklerinin toplam azot içeriğini belirlemek açısından azot içeriği salisilik + sülfürik asit + tuz karışımı ile yaş yakmaya tabi tutulduktan sonra mikrokjheldahl yakma ünitesinde destilasyon sonucu titrasyon ile tam otomatik azot analizöründe belirlenmiştir (Bremner, 1996).

\section{İstatistiksel Değerlendirmeler}

Tam şansa bağlı faktoriyel deneme desenine göre, varyans analizleri, ortalamaların karşılaştırılması ve Duncan çoklu karşılaştırma testleri yapılmıştır (Yıldız ve Bircan, 1994). Elde edilen veri setleri SPSS-22 software kullanılarak değerlendirilecektir.

\section{Biyo-Nanoçinkooksit (NP-ZnO) Gübre Formülasyonlarının Oluşturulması}

Formülasyon için kullanılacak bakteriler üretilerek nanopartiküllerle canlılık tesleri yapılmıştır. Her bakteri türü ayrı ayrı seçilmiş farklı konsantrasyonlardaki nanopartiküllerle sıvı bir formülasyon oluşturulacak şekilde taşıyıcı ortam (silempe) eklenerek oluşturulmuştur.

\section{İş Akış Şeması, Bakteriyel Canıılık Testi ve Sıvı Taşıyı Ortamın Kullanılması}

Çalışma Atatürk Üniversitesi Ziraat Fakültesi Toprak Bilimi Bitki Besleme Bölümü ve Tarımsal Biyoteknoloji Bölümü laboratuvarlarında gerçekleştirilmiştir.

\section{Bakteriyel canlılık testi ve sıvı taşıyı ortamın kullanılması}

Yapılan bu deneyler sonucunda $10^{9}$ oranında seçilen bu üç bakterinin ortamda bulunan çinkooksit nanopartikülleri ve tuzluluk koşullarından etkilenmedikleri tespit edilmiştir. Kullanılan şilempe sayesinde ortamda bakteriyel canlılıklar devam ettirilmiştir. Sıvı taşıyıcı olarak şilempe (w/w, 1/100 deiynize su) ve 40 mg ZnO nanopartikülü Raliya ve ark. (2015) tarafından yapılan çalışmaya göre bitkiye toksik etki oluşturmayacak konsantrasyon değerleri dikkate alınarak bu doz seçilmiştir) ayrı ayrı eklenerek birer litrelik üç farklı formülasyon için karıştırılılarak üç adet biyo-nano gübre formülasyonu elde edilmiştir.

Çizelge 1. Üç Farklı Nano-Biyo Gübre formülasyonlarının bir mililitresinde bulunan Bakteri Sayısı

\begin{tabular}{lll}
\hline Bakteri & Kod & kob/ml \\
\hline Bacillus subtilis & $\mathrm{N} 28$ & $1 \times 10^{8}$ \\
Bacillus pumilis & $\mathrm{N} 1$ & $5,7 \times 10^{7}$ \\
Lactobacillus casei & $\mathrm{Nm} 24$ & $2,9 \times 10^{8}$ \\
\hline
\end{tabular}




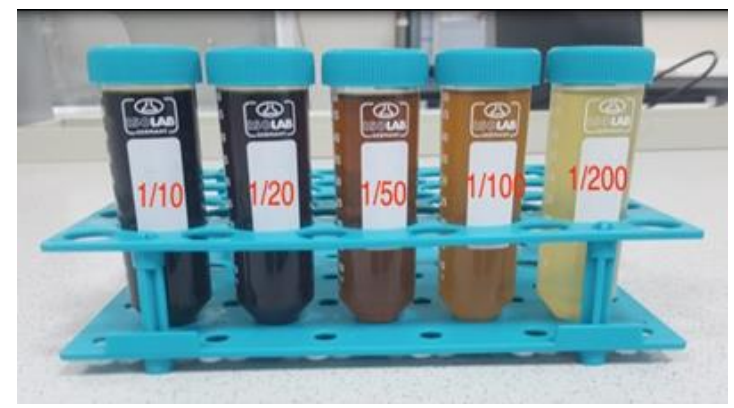

Şekil 6. Bakteriler için sıvı taşıyıcı olarak kullanılan şilempede yapılan seyreltmeler

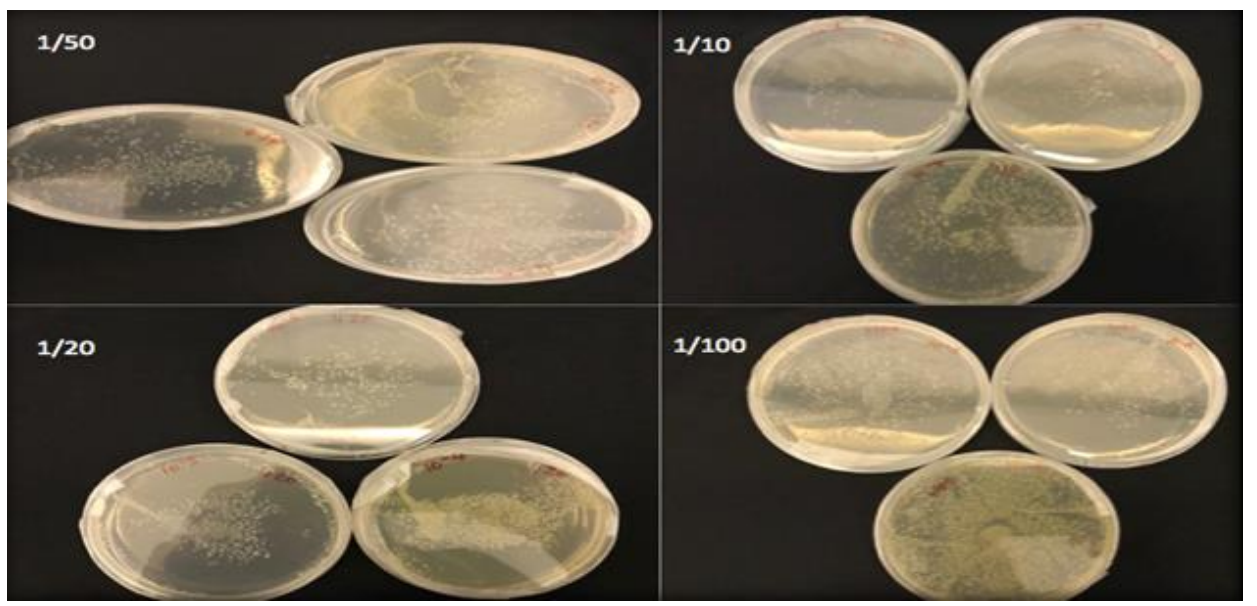

Şekil 7. Sıvı nano-biyo formülasyonlarında bakterilere besin sağlamak için kullanılan şilempenin üç haftalık inkübasyonu sonucunda $(\mathrm{w} / \mathrm{w}, 1 / 10,1 / 20,1 / 50,1 / 100)$ seyreltik oranlarına üç bakteride gelişim durumları

Yapılan deneyler sonucunda seçilen bu üç bakterinin (Bacillus pumilis (N1), Bacillus subtilis (N28), Lactobacillus casei (Nm24) ortamda bulunan çinkooksit nanopartikülleri ve tuzluluk koşullarından etkilenmedikleri tespit edilmiştir. Kullanılan şilempe sayesinde ortamda bakteriyel canlılıklar devam ettirilmiştir. Sıvı taşıyıcı olarak şilempe (w/w, 1/100 deiynize su) ve $40 \mathrm{mg} \mathrm{ZnO}$ nanopartikülü (Raliya vd, 2015 yılında yaptıkları çalışmaya göre bitkiye toksik etki yaratmayacak şekilde bu doz seçilmiştir) ayrı ayrı eklenerek birer litrelik üç farklı formülasyon için karıştırılılarak üç adet biyo-nano gübre formülasyonu elde edilmiştir. Yapılan sera deneme sürecinde merkezi otomasyon sistem tarafından ortam şartları kontrollü bir şekilde takip edilmiştir. Deneme, domateslerin çiçeklenme başlangıcına kadar 8 hafta uygulanmış ve sonlandırılmıştır.

\section{Bulgular ve Tartışma}

Bu çalışmada üç farklı mikroorganizma (Bacillus subtilis $1 \times 10^{8}$, Bacillus pumilis $5,7 \mathrm{x} 10^{7}$, Lactobacillus casei $\left.2,9 \times 10^{8}\right)$ ile birlikte çinkooksit nanopartikül içerikli formülasyonu $(0,20,40 \mathrm{mg} / \mathrm{l})$ olacak şekilde sera koşullarında uygulanarak bitkinin 90 günlük periyotta gelişme sürecine etkileri araştırılmıştır. 90 günlük yetiştirme periyodu sonucunda alınan üst aksam ve kök kısımları analiz yapılarak değerlendirilmiştir.

\section{Saksı Bitkilerin Üst Aksam Analiz Sonuçları}

Domates bitkisine ait sera denemesi sonucu hasat edilen bitki yapraklarının analizi sonucunda ortaya çıkan değerler Çizelge 2, 3 ve 4'de verilmiştir.

\section{Nano-biyo gübrenin taramalı elektron mikroskobu (SEM) ile görüntülenmesi}

Taramalı elektron mikroskop analizleriyle numunelerin görüntüleri alınmıştır. Burada 2 mikrometrelik bakteri boyutlarıyla birlikte çinkooksit nanopartiküllerinin boyutları $35 \mathrm{~nm}$ ve hegzagonal yapıya olduğu, ZnO nanopartikülleri ile birlikte bakteri gruplarının birlikte yaşadığı Nano-Biyo gübre formülasyonları görülmektedir. 
Çizelge 2. Bakteri uygulamaları, nanopartikül ve nano-bakteri uygulamalarının domates bitkisinin makro element (Toplam Azot, Fosfor, Kalsiyum, Potasyum, Magnezyum) üzerine etkilerine ait analiz sonuçları

\begin{tabular}{|c|c|c|c|c|c|c|}
\hline Uygulamalar & Tuz $(\mathrm{dS} / \mathrm{m})$ & $\mathrm{N}(\%)$ & $\mathrm{Mg}(\mathrm{mg} / \mathrm{kg})$ & $\mathrm{P}(\%)$ & $\mathrm{K}(\%)$ & $\mathrm{Ca}(\%)$ \\
\hline Kontrol & 50 & $\begin{array}{c}1,960 \\
\pm 0,200 \mathrm{c}\end{array}$ & $\begin{array}{c}0,159 \\
\pm 0,001 \mathrm{bc}\end{array}$ & $\begin{array}{r}0,368 \\
\pm 0,038 \mathrm{~b}\end{array}$ & $\begin{array}{c}2,523 \\
\pm 0,001 \mathrm{~d}\end{array}$ & $\begin{array}{c}0,810 \\
\pm 0,005 \mathrm{~b}\end{array}$ \\
\hline ZnNanops & 50 & $\begin{array}{c}2,980 \\
\pm 0,120 \mathrm{~d} \\
\end{array}$ & $\begin{array}{c}0,161 * \\
\pm 0,001 \text { bcd }\end{array}$ & $\begin{array}{c}0,365^{*} \\
\pm 0,001 \text { a }\end{array}$ & $\begin{array}{c}2,626 \\
\pm 0,001 \mathrm{~h} \\
\end{array}$ & $\begin{array}{c}0,790^{*} \\
\pm 0,004 \mathrm{~b}\end{array}$ \\
\hline B. pumilis (N1) & 50 & $\begin{array}{r}2,320 \\
\pm 0,440 \mathrm{~d} \\
\end{array}$ & $\begin{array}{c}0,156 * \\
\pm 0,002 \mathrm{~b} \\
\end{array}$ & $\begin{array}{c}0,387^{*} \\
\pm 0,009 \mathrm{c} \\
\end{array}$ & $\begin{array}{c}2,571 \\
\pm 0,009 \mathrm{f} \\
\end{array}$ & $\begin{array}{c}0,800^{*} \\
\pm 0,005 \mathrm{~b} \\
\end{array}$ \\
\hline B. pumilis (N1)+20 ZnNanops & 50 & $\begin{array}{c}3,750 \\
\pm 0,220 \mathrm{~cd} \\
\end{array}$ & $\begin{array}{c}0,152 * \\
\pm 0,001 \mathrm{ab} \\
\end{array}$ & $\begin{array}{c}0,395^{*} \\
\pm 0,001 \mathrm{~d} \\
\end{array}$ & $\begin{array}{c}2,776 \\
\pm 0,001_{1} \\
\end{array}$ & $\begin{array}{c}0,810^{*} \\
\pm 0,003 \mathrm{~b} \\
\end{array}$ \\
\hline B. pumilis (N1)+40 ZnNanops & 50 & $\begin{array}{c}4,500 \\
\pm 0,340 \\
\end{array}$ & $\begin{array}{c}0,170 \\
\pm 0,003 \mathrm{e}\end{array}$ & $\begin{array}{c}0,386^{*} \\
\pm 0,001 \mathrm{c}\end{array}$ & $\begin{array}{c}2,464 \\
\pm 0,001 \mathrm{c}\end{array}$ & $\begin{array}{c}0,840 \\
\pm 0,004 \mathrm{c}\end{array}$ \\
\hline B. subtilis (N28) & 50 & $\begin{array}{c}1,650 \\
\pm 0,900 \mathrm{c} \\
\end{array}$ & $\begin{array}{c}0,192 \\
\pm 0,003 \mathrm{f} \\
\end{array}$ & $\begin{array}{c}0,402 \\
\pm 0,001 \mathrm{e} \\
\end{array}$ & $\begin{array}{c}2,433 \\
\pm 0,001 \mathrm{a} \\
\end{array}$ & $\begin{array}{c}0,870 \\
\pm 0,003 \mathrm{de} \\
\end{array}$ \\
\hline B. subtilis (N28)+20 ZnNanops & 50 & $\begin{array}{c}3,010 \\
\pm 0,220 \mathrm{~cd} \\
\end{array}$ & $\begin{array}{c}0,141 \\
\pm 0,004 \mathrm{a}\end{array}$ & $\begin{array}{c}0,429 \\
\pm 0,001 \mathrm{f} \\
\end{array}$ & $\begin{array}{c}2,446 \\
\pm 0,002 \mathrm{~b} \\
\end{array}$ & $\begin{array}{c}0,882 \\
\pm 0,005 \mathrm{e} \\
\end{array}$ \\
\hline B. subtilis (N28)+40 ZnNanops & 50 & $\begin{array}{c}3,290 \\
\pm 0,560 \text { ef } \\
\end{array}$ & $\begin{array}{c}0,170 \\
\pm 0,001 \mathrm{de} \\
\end{array}$ & $\begin{array}{c}0,436 \\
\pm 0,002 \mathrm{~g} \\
\end{array}$ & $\begin{array}{c}2,594 \\
\pm 0,003 \mathrm{~g}\end{array}$ & $\begin{array}{c}0,881 \\
\pm 0,003 \mathrm{e}\end{array}$ \\
\hline L. casei (Nm24) & 50 & $\begin{array}{c}5,230 \\
\pm 0,12 \mathrm{ab} \\
\end{array}$ & $\begin{array}{c}0,172 \\
\pm 0,001 \mathrm{e} \\
\end{array}$ & $\begin{array}{c}0,430 \\
\pm 0,001 \mathrm{f} \\
\end{array}$ & $\begin{array}{r}2,439 \\
\pm 0,002 \mathrm{a} \\
\end{array}$ & $\begin{array}{c}0,860 \\
\pm 0,005 \mathrm{~cd} \\
\end{array}$ \\
\hline L. casei $(\mathrm{Nm} 24)+20 \mathrm{ZnNanops}$ & 50 & $\begin{array}{c}5,560 \\
\pm 0,180 \mathrm{ab} \\
\end{array}$ & $\begin{array}{c}0,170 \\
\pm 0,001 \mathrm{de}\end{array}$ & $\begin{array}{c}0,371^{*} \\
\pm 0,001 \mathrm{~b}\end{array}$ & $\begin{array}{c}2,522^{*} \\
\pm 0,002 \mathrm{~d}\end{array}$ & $\begin{array}{c}0,783 \\
\pm 0,005 \mathrm{a}\end{array}$ \\
\hline L. casei $(\mathrm{Nm} 24)+40 \mathrm{ZnNanops}$ & 50 & $\begin{array}{c}6,120 \\
\pm 0,760 \mathrm{a} \\
\end{array}$ & $\begin{array}{c}0,167 \\
* \pm 0,001 \mathrm{cde}\end{array}$ & $\begin{array}{c}0,386^{*} \\
\pm 0,001 \mathrm{c}\end{array}$ & $\begin{array}{c}2,561 \\
\pm 0,001 \mathrm{e}\end{array}$ & $\begin{array}{c}0,866 \\
\pm 0,005 \mathrm{cde} \\
\end{array}$ \\
\hline Ortalama & & $\begin{array}{c}2,550 \\
\pm 0,210\end{array}$ & $\begin{array}{c}0,166 \\
\pm 0,001\end{array}$ & $\begin{array}{c}0,396 \\
\pm 0,001\end{array}$ & $\begin{array}{c}2,542 \\
\pm 0,002\end{array}$ & $\begin{array}{c}0,834 \\
\pm 0,005\end{array}$ \\
\hline
\end{tabular}

Çizelge 3. Bakteri uygulamaları, nanopartikül ve nano-bakteri uygulamalarının domates bitkisinin yaprak kuru madde miktarı ve mineral içerik (Sodyum, Çinko, Demir) üzerine etkilerine ait analiz sonuçları

\begin{tabular}{|c|c|c|c|c|c|}
\hline Uygulamalar & $\begin{array}{c}\text { Tuz } \\
(\mathrm{dS} / \mathrm{m})\end{array}$ & $\begin{array}{l}\text { Kuru madde } \\
\text { miktarı (g) }\end{array}$ & $\mathrm{Na}(\mathrm{mg} / \mathrm{kg})$ & $\mathrm{Zn}(\mathrm{mg} / \mathrm{kg})$ & $\mathrm{Fe}(\mathrm{mg} / \mathrm{kg})$ \\
\hline Kontrol & 50 & $1,85 \pm 0,10 a b c$ & $778 \pm 0,71 \mathrm{e}$ & $38,77 \pm 0,1 \mathrm{a}$ & $141,27 \pm 0,145 b$ \\
\hline ZnNanops & 50 & $1,97 \pm 1,14 \mathrm{abc}$ & $742 \pm 0,73 d$ & $39,61^{*} \pm 0,1 \mathrm{ab}$ & $143,69 \pm 0,035 c$ \\
\hline B. pumilis (N1) & 50 & $2,33 \pm 0,20 \mathrm{bcd}$ & $683 \pm 0,69 a$ & $43,89 \pm 0,05 \mathrm{~cd}$ & $144,26 \pm 0,350 \mathrm{~cd}$ \\
\hline B. pumilis (N1)+20 ZnNanops & 50 & $2,39 \pm 0,16 \mathrm{e}$ & $605 \pm 0,75 c$ & $40,85 \pm 0,15 b$ & $155,71 \pm 0,1 \mathrm{f}$ \\
\hline B. pumilis (N1)+40 ZnNanops & 50 & $2,19 \pm 0,06 \mathrm{bcd}$ & $805 \pm 0,72 b$ & $43,52 \pm 0,045 \mathrm{~cd}$ & $144,79 \pm 0,250 \mathrm{~cd}$ \\
\hline B. subtilis (N28) & 50 & $1,19 \pm 0,08 a$ & $921 \pm 0,76 f$ & $44,32 \pm 0,2 \mathrm{de}$ & $131,1 \pm 0,40 a$ \\
\hline B. subtilis (N28)+20 ZnNanops & 50 & $1,5733 \pm 0,288 d$ & $612 \pm 0,691$ & $45,53 \pm 0,1 \mathrm{e}$ & $148,28 \pm 0,185 \mathrm{e}$ \\
\hline B. subtilis (N28)+40 ZnNanops & 50 & $1,24 \pm 0,36 \mathrm{~cd}$ & $694 \pm 0,71 \mathrm{k}$ & $47,87 \pm 0,1 \mathrm{f}$ & $143,39 \pm 0,130 c$ \\
\hline L. casei $(\mathrm{Nm} 24)$ & 50 & $2,50 \pm 0,56$ ef & $757 \pm 0,591$ & $47,42 \pm 0,05 f$ & $145,75 \pm 0,1 d$ \\
\hline L. casei $(\mathrm{Nm} 24)+20 \mathrm{ZnNanops}$ & 50 & $2,57 \pm 0,54 \mathrm{ef}$ & $720 \pm 0,62 \mathrm{~h}$ & $42,8 \pm 0,1 c$ & $149,15 \pm 0,15 \mathrm{e}$ \\
\hline L. casei $(\mathrm{Nm} 24)+40 \mathrm{ZnNanops}$ & 50 & $2,65 \pm 0,12 \mathrm{ef}$ & $726 \pm 0,64 \mathrm{~g}$ & $38,22^{*} \pm 0,78 \mathrm{a}$ & $149,17 \pm 0,29 \mathrm{~g}$ \\
\hline Ortalama & & $1,86 \pm 0,28 \mathrm{e}$ & $731,68 \pm 0,65$ & $430,95 \pm 0,18$ & $146,1818 \pm 0,19$ \\
\hline
\end{tabular}

*Uygulama grupları arasında kontrole göre oluşan fark önemli $(\mathrm{p} \leq 0,05)$ değil 
Çizelge 4. Bakteri uygulamaları, nanopartikül ve nano-bakteri uygulamalarının domates bitkisinin yaprakta mikro element (Mangan, Bakır, Bor) üzerine etkilerine ait analiz sonuçları

\begin{tabular}{lcccc}
\hline Uygulamalar & $\begin{array}{c}\text { Tuz } \\
(\mathrm{dS} / \mathrm{m})\end{array}$ & $\mathrm{Mn}(\mathrm{mg} / \mathrm{kg})$ & $\mathrm{Cu}(\mathrm{mg} / \mathrm{kg})$ & $\mathrm{B}(\mathrm{mg} / \mathrm{kg})$ \\
\hline Kontrol & 50 & $55,80 \pm 0,106 \mathrm{ab}$ & $63,76 \pm 0,148 \mathrm{~d}$ & $15,07 \pm 0,141 \mathrm{~b}$ \\
\hline ZnNanops & 50 & $57,02 \pm 0,127 \mathrm{c}$ & $60,99 \pm 0,304 \mathrm{a}$ & $16,02 \pm 0,127 \mathrm{~cd}$ \\
\hline B. pumilis (N1) & 50 & $55,80^{*} \pm 0,707 \mathrm{ab}$ & $61,57 \pm 0,007 \mathrm{ab}$ & $17,08 \pm 0,509 \mathrm{ef}$ \\
\hline B. pumilis (N1)+20 ZnNanops & 50 & $59,02 \pm 0,127 \mathrm{~d}$ & $67,62 \pm 0,127 \mathrm{e}$ & $17,84 \pm 0,254 \mathrm{f}$ \\
\hline B. pumilis (N1)+40 ZnNanops & 50 & $58,38 \pm 0,282 \mathrm{~d}$ & $61,78 \pm 0,141 \mathrm{bc}$ & $19,52 \pm 0,190 \mathrm{e}$ \\
\hline B. subtilis (N28) & 50 & $64,15 \pm 0,424 \mathrm{ef}$ & $62,92^{*} \pm 0,113 \mathrm{~cd}$ & $19,71 \pm 0,381 \mathrm{f}$ \\
\hline B. subtilis (N28)+20 ZnNanops & 50 & $56,74^{*} \pm 0,141 \mathrm{bc}$ & $73,12 \pm 0,466 \mathrm{~g}$ & $13,17 \pm 0,707 \mathrm{a}$ \\
\hline B. subtilis (N28)+40 ZnNanops & 50 & $63,22 \pm 0,424 \mathrm{e}$ & $68,40 \pm 0,142 \mathrm{e}$ & $20,59 \pm 0,042 \mathrm{f}$ \\
\hline L. casei $(\mathrm{Nm} 24)$ & 50 & $65,27 \pm 0,212 \mathrm{f}$ & $61,09 \pm 0,572 \mathrm{ab}$ & $17,67 \pm 0,0636 \mathrm{e}$ \\
\hline L. casei $(\mathrm{Nm} 24)+20$ ZnNanops & 50 & $55,05^{*} \pm 0,424 \mathrm{a}$ & $68,88 \pm 0,145 \mathrm{f}$ & $15,46^{*} \pm 0,127 \mathrm{bc}$ \\
\hline L. casei $(\mathrm{Nm} 24)+40$ ZnNanops & 50 & $57,55 \pm 0,141 \mathrm{c}$ & $63,56^{*} \pm, 212 \mathrm{~d}$ & $16,85 \pm 0,190 \mathrm{de}$ \\
\hline Ortalama & & $59,05 \pm 0,191$ & $64,88 \pm 0,155$ & $17,184 \pm 1,870$ \\
\hline
\end{tabular}

*Uygulama grupları arasında kontrole göre oluşan fark önemli $(\mathrm{p} \leq 0,05)$ değildir

Çalışmada kullanılan ZnO nanopartikül tabanlı biyolojik gübreninde mineral içerik açısından kontrole göre B. subtilis (N28) + 40 ZnNanops uygulama grubu fosfor içeriğini \%15,64, potasyum içeriğini \% 2,75, $B$. subtilis (N28) + 40 ZnNanops uygulama grubu kalsiyum içeriğini \% 8,2 B. subtilis uygulama grubu magnezyum içeriğini \% 17,19 B. subtilis (N28) +40 ZnNanops uygulama grubu çinko içeriğini \% 19,01, $B$. subtilis uygulama grubu demir içeriğini $\% 7,75$ L. casei uygulama grubu mangan içeriğini $\% 14,6, B$. subtilis (N28)+20 ZnNanops uygulama grubu bakır içeriğini \% 12,71, B. pumilis (N28)+40 ZnNanops bor içeriğini \% 23,8, L. casei (Nm24) + 40ZnNanops uygulama grubu toplam azot içeriğini yaklaşık üç kat arttırdığ gözlemlenmiştir. Bu sonuçlar doğrultusunda nanopartikül ve bakteri uygulamalarının bitkinin tuz stresine karşı bir direnç oluşturabileceği gözlemlenmiştir. Uygulamalar sonucunda kuru madde içeriğinin $(\% 31,2)$, fosfor içeriği \%15,64, potasyum içeriği \% 2,75, kalsiyum içeriğini \% 8,2, magnezyum içeriği \%17,19, B. subtilis (N28)+40 ZnNanops uygulama grubu çinko içeriği \%19,01, demir içeriği \%7,75, mangan içeriği \% 14,6 , B bakır içeriğini \%12,71, B. pumilis bor içeriğini \% 23,8, toplam azot içeriğinin ise yaklaşık 3 kat arttırdığı gözlemlenmiştir. Tüm bu bilgilerin ıșığında bakteri, nanopartikül, bakteri ile birlikte nanopartikül uygulamaları tuz stresi koşullarında bitkinin mineral içeriğini yer yer kritik aralık düzeyine yükseltmiştir. Ancak bitkiler henüz genç çiçeklenme aşamasına geçmediği için mineral içerik değerlerindeki yükselme normal kabul edilmektedir. Her besin elementi için her bitkinin belirli ve genetik olarak değişmeyen besin alım potansiyeli vardır. Genetik olarak denetlenen besin alım potansiyeli nedeniyle, yeşil bitki dokularının azot $(\mathrm{N})$ ve fosfor (P) kapsamlarının 10, mikro besin elementleri kapsamlarının 100-1000 katı fazla olabilmektedir. Bu genel görünüm tüm yüksek bitkiler için geçerlidir. Aynı bitkide değişik organların mineral kapsamları da farklıdır. Genelde yaprak, sap ve kök gibi vejetatif organların mineral içerikleri meyve, yumru ve tohum gibi üretken organlara göre daha değișkendir. Genç bitki dokularının N, P ve potasyum $\mathrm{K}$ yönünden varsıl olmalarına karşın, yaşlı bitkiler ve olgun dokular kalsiyum (Ca), mangan (Mn), demir (Fe) ve bor (B) yönünden daha varsıldırlar (Mengel ve Kirkby, 2001). Fakat bitkilerin gelişim periyodu boyunca genç ve yaşlılık durumlarında mineral içerikleri değișebileceğinden uygulamalarımızın domates verim ve kalitesi üzerinde olumlu ya da olumsuz bir etki yaratabileceğini hakkında bir varsayımda bulunmak için erken olacaktır. Araștırma çalıșmasında nanopartikül ve mikrobiyal gübre gibi iki önemli unsurun birlikte kombinasyon olușturabildiğini, biyolojik aktivitenin çalışır olduğu ve kısmen organomineral gübreymiş gibi yeni bir formülasyonun (mikroorganizmaların farklı nano tabanlı minerallerle birleştirilip) akademik ölçekte kullanışlı olup olmadığını deneyerek, gerek bilimsel çalışmalarla ve gerekse tarım sektörü açısından birçok yeniliğe olası ışık tutabileceğine dikkat çekilmeye çalışılmıştır. Gübre sektörü açısından yeni bir ürünün altyapısı, araştırmacılar açısından bitki besleme veri tabanında, tarımsal nanobiyoteknoloji bilimsel disiplini ölçeğinde öncü bir çalışmanın altyapısını oluşturabileceği muhtemeldir. 


\section{Teşekkür}

Doktora tez kapsamında hazırlanan bu yayında benden desteğini hiç esirgemeyen değerli danışmanım Prof. Dr. Sayın Nesrin YILDIZ bașta olmak üzere, Prof. Dr. Sayın Neslihan DİKBAȘ, Prof. Dr. Faruk ÖZKUTLU, Prof. Dr. Sayın Metin TURAN ve Doc.Dr. Müdahir ÖZGÜL hocalarıma ayrı ayrı teşekkür ederim.

\section{Kaynaklar}

Alharby HF, 2016. The alteration of mRNA expression of SOD and GPX genes, and proteins in tomato (Lycopersicon esculentum Mill) under stress of $\mathrm{NaCl}$ and/or ZnO nanoparticles. Saudi Journal of Biological Sciences 23: 773-781

Bilgin N, Ylldız, N, 2008. Besin kültüründe yetiştirilen (Kaya-F1) domates çeşidinin (Lycopersicon esculentum) artan nacl uygulamalarına toleransı ve tuzluluk stresinin kuru madde miktarı ile bitki mineral madde içeriğine etkisi. Atatürk Üniversitesi Ziraat Fakültesi Dergisi 9: 15-21

Bremner JM, 1996. Nitrogen Total. In: Sparks, D.L., Ed., Methods of Soil Analysis Part 3: Chemical Methods, SSSA Book Series 5, Soil Sci. Soci. of America, Madison, Wisconsin, 1085-1122.

Flores HE, Galston AW, 1982. Analysis of polyamines in higher plants by high performance liquid chromatography. Plant Physiology 69, 701-706.

Gill SS, Tuteja N, 2010. Reactive oxygen species and antioxidant machinery in abiotic stress tolerance in crop plants. Plant Physiology and Biochemistry 48, 909-930.

Iqbal M, Ashraf M, 2006. Wheat seed priming in relation to salt tolerance: growth, yield and levels of free salicylic acid and polyamines. Annales Botanici Fennici 43, 250-259.

Kazan K, 2015. Diverse roles of jasmonates and ethylene in abiotic stress tolerance. Trends in Plant Science 20, 219-229.

Khan MIR, Iqbal N, Masood A, Mobin M, Anjum NA, Khan NA, 2016. Modulation and significance of nitrogen and sulfur metabolism in cadmium challenged plants. Plant Growth Regulation 78: 1-11.

Kotuby J, Koenig R, Kitchen B, 1997. Salinity and Plant Tolerance. Utah State Üniversity Extension. AG-SO-03., Utah.plants. Environ. Sci. Technol. 48, 4376e4385.

Lee CW, Mahendra S, Zodrow K, Li D, Tsai Y, Braam J, 2010. Developmental phytotoxicity of metal oxide nanoparticles to Arabidopsis Thaliana. Environmental Toxicology and Chemistry 29, 669-675.

Lin D, Xing B, 2007. Phytotoxicity of nanoparticles: inhibition of seed germination and root growth. Environmental Pollution 150, 243-250.

Lopez MV, Satti SME, 1996. Calcium and potassium-enhanced growth and yield of tomato under sodium chloride stress, Plant Science 114, 19-27.

Mengel K, Kirkby EA, 2001. Principles of Plant Nutrition. ISBN 0-7923-7150-X (HB) Published by Kluwer Academic Publishers. The Netherlands.

Mertens D, 2005a. AOAC official method 922.02. In: Horwitz, W., Latimer, G.W. (Eds.), Plants Preparation of Laboratory Sample. Official Methods of Analysis, 18th ed. AOAC-International Suite, Gaitherburg, MD, USA, (Chapter 3), pp. 1-2. [18].

Mertens D, 2005b. AOAC official method 975.03. In: Horwitz, W., Latimer, G.W.(Eds.), Metal in Plants and Pet Foods. Official Methods of Analysis, 18th ed. AOAC-International Suite, Gaitherburg, MD, USA, (Chapter 3), pp. 3- 4.

Mosanna R, Khalilvand BE, 2015. Morpho-physiological response of maize (Zea mays L.) to zinc nano-chelate foliar and soil application at different growth stages. Journal on New Biological Reports 4, 46-50.

Prasad TN, Sudhakar P, Sreenivasulu Y, Latha P, Munaswamya V, Raja Reddy, K Sreeprasad TS, Sajanlal PR, Pradeep T, 2012. Effect of nanoscale zinc oxide particles on the germination, growth and yield of peanut. Journal of Plant Nutrition 35, 905-927.

Singh NB, Amist N, Yadav K, Singh D, Pandey JK, Singh SC, 2013. Zinc oxide nanoparticles as fertilizer for the germination, growth and metabolism of vegetable crops. Journal of Nanoengineering and Nanomanufacturing 3 , 353-364.

Smith W.E, Dent G, 2005. Modern Raman Spectroscopy - A Practical Approach, John Wiley \& Sons Ltd, Chichester, s.135-136.

Smith, TA, 1985. Polyamines. Annual Review of Plant Physiology 36, 117-143.

Soydam S, Aras S, 2013. Relationships among lipid peroxidation, SOD enzyme activity, and SOD gene expression profile in Lycopersicum esculentum L. exposed to cold stress. Genetics and Molecular Research 12, 3220-3229.

Subramanian KS, Sharmila RC, 2012. Ball milled nanosized zeolite loaded with zinc sulfate: a putative slow release $\mathrm{Zn}$ fertilizer. Int. J. Innov. Hortic. 1, 33-40.

Yıldız N, 2012. Bitki Beslemenin Esasları ve Bitkilerde Beslenme Bozukluğu Belirtileri. Eser ofset matbaacılık, Erzurum.

Yıldız N, Bircan H, 1994. Araştırma ve Deneme Metodları Atatürk Üni. Ziraat Fak. Yay. No. 697. Erzurum.

Yıldız N, Canbolat M. ve Aydın A, 2000. Influence of increasing $\mathrm{NaCl}$ and $\mathrm{NaHCO3}$ on tomato plant grown in hydroculture. Workshop on Enviromental impact of water quality, irrigation practices. Soil type and crop interactions. November 7, 2000. Antalya-Turkey.

Zhao L, Peralta-Videa JR, Rico CM, Hernandez-Viezcas JA, Sun Y, Niu G, Servin A, Nunez JE, Duarte-Gardea M, GardeaTorresday JL, 2014. CeO2 and $\mathrm{ZnO}$ nanoparticles change the nutritional qualities of cucumber (Cucumis sativus). Journal of Agricultural and Food Chemistry. 62, 2752-2759. 